\title{
The development and the structure of industry in the district of Ümraniye, Istanbul
}

\begin{abstract}
Istanbul, has been one of the leading centers of development in parallel with the development in outward-oriented economy and industrialization in the 1980's in Turkey. The district which looked like a village in 1960s, having experienced rapid urbanisation and industrialisation, is now looking far from its earlier appearance. During the period of migration from suburbs to the cities, one of those who took in the biggest share of people is Ümraniye. The purpose of this study is to determine the historical development of industrialization in Ümraniye and the causes of this development, its structure, and the distribution of its sectors. As an operation of a regional industry, this study handles the features of the location of Ümraniye District, the factors that affect the industry in the district, distribution of industrial sectors, and environmental issues.
\end{abstract}

Keywords: distribution; industrialization; urbanisation; ümraniye

\section{INTRODUCTION}

Istanbul province, which is located in the northwest Marmara Region of Turkey, is situated on both sides of the Istanbul Bosphorus Strait, where the continents of Europe and Asia are closest to each other. Istanbul province consists of a total of 39 districts, 29 of which are on the European continent and 10 of which are on the Asian continent. Ümraniye District, which consists of the study area, is one of them. Ümraniye District is on the Asian side of Istanbul province within the boundaries of Istanbul Metropolitan Municipality. The district is bordered by Sancaktepe in the east, Ataşehir in the south, Üsküdar in the west and Çekmeköy and Beykoz districts in the north. Ümraniye covers the approximate area of $45 \mathrm{~km}^{2}$ and its elevation is 120 meters above sea level; the elevation reaches 180 meters in Yukaridudullu towards the east (Fig. 1).

The purpose of this study is to display the historical development of industrialization in Ümraniye District, the reasons behind the progress, as well as the structure and sectoral distribution. This study, which is a region-based industrial study, presents the characteristics of Ümraniye in terms of location, factors which have an impact on industry in the district, the sectoral distribution of the industry, and the employment status during the periods of crisis. 


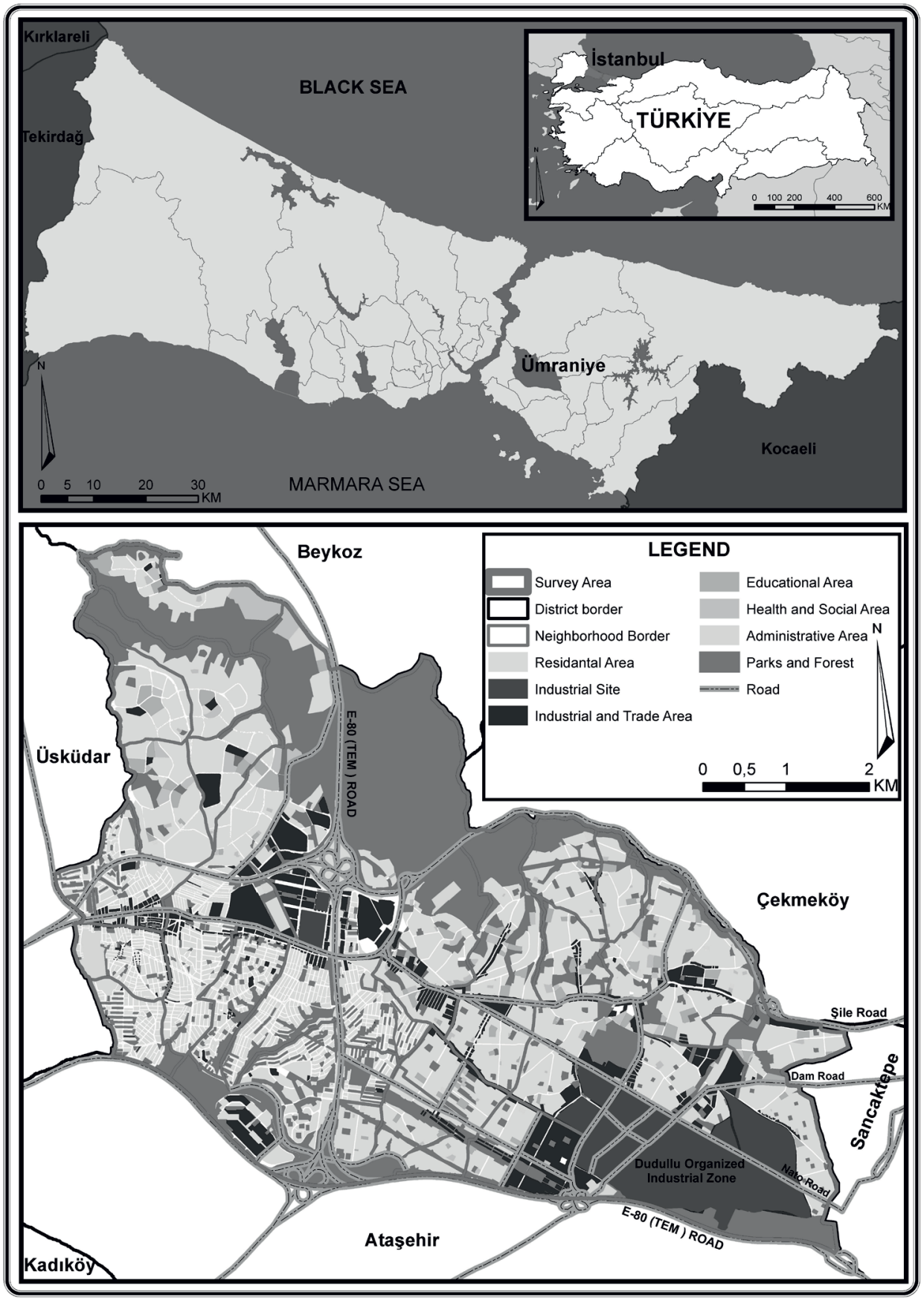

Fig. 1. Location map of Ümraniye District and urban functions 
The intensification and the propagation of economic activities in different areas is the result of a functional interaction of economic elements. Thus central venues where economic activities are concentrated are established and each one of these central venues becomes a center which attracts all forms of economic activity. The main center where economic activity is concentrated in Turkey is İstanbul (Mutluer, 1995: 1). Industrial facility developed in the urban areas of the cities and expanded to the outskirts of these cities and thus influenced the spatial expansion of cities (Tümertekin, 1984: 109-128). Areas which have been opened for new industrialization in Turkey, and large cities, such as Istanbul, consist mainly of agricultural areas, old recreation areas and suburbs on the outskirts of the cities (Özgüç, 1986-87: 35). Since the second half of the 1980's a decentralization movement has started as a result of the rapid and unplanned urbanization and increase in land prices in Istanbul, and the industrial facilities within Istanbul have started to relocate to the outside of the city (Karakuyu, 2008: 21-49).

Various types of migration significantly contribute to the historical development in the settlement of Ümraniye, which is one of these areas. Until 1955, the urban core of Ümraniye consisted of the neighborhoods of Atatürk, Namık Kemal, İstiklal, Atakent, Çakmak and İnk1lap, which retained their rural features and formed the center of the city. Before that date, in the last era of the Ottoman Empire, the migrants from the Balkans had settled in the area. Later a migration from Anatolia added to the external migrations, and the rural settlements here grew and, in time, the area developed an urban quality. With the opening of the Üsküdar-Şile highway, the area which formed the primary core of the city was exposed to development and the accompanying population growth. Ümraniye and its environs started to attract more population with the new employment opportunities, presented by the opening of rock and brick quarries, as well as by industrial action. This rural settlement, which housed 30-40 households during the first years of the Republic, became a significant urban settlement, with 14800 inhabitants in 1965, 71954 in 1980, 242091 in 1990, 440859 in 2000 and finally 645237 inhabitants in 2012. After the 1980's Ümraniye, which is a part of Istanbul, became one of the leading centers, combining the outward oriented development of the economy and industrialization occuring in Turkey. The rapid urbanization and industrialization which occured after these years in terms of the phenomenon of migration from rural areas to urban areas, changed the appearance of the district in a major way.

According to the data from the Development Bank of Turkey (TKB) and the Turkish Statistical Institute (TÜIK), the industry of Istanbul is significant to the industrial sector of Turkey. The province of Istanbul is a significant metropolitan area which hosts approximately $19 \%$ of the population of Turkey in an area which corresponds to $0.7 \%$ of the area of Turkey. In 2012, 24821000 peoplepeople in Turkey were employed in various sectors. 18\% (4 493000 ) of this employed population is in Istanbul. A review of the sectoral distribution of the employed population in Turkey reveals that Istanbul province hosts $25.5 \%$ of the industrial sector, $23 \%$ of the service sector and $0.4 \%$ of the agricultural sector (Tab. 1). $0.6 \%$ of the active population in Istanbul province is employed in the agricultural sector, while $36.7 \%$ are employed by the industrial sector, and $62.7 \%$ by the service sector (TKB, 2012; TÜİK, 2012). 
Tab. 1. The population employed in Turkey and the status of the Istanbul Province (x1000)

\begin{tabular}{|l|r|r|r|r|}
\hline $\begin{array}{c}\text { The population } \\
\text { employed }\end{array}$ & Agriculture & Industry & Service & Total \\
\hline İstanbul Province & 26 & 1649 & 2818 & 4493 \\
\hline$\%$ & 0.6 & 36.7 & 62.7 & 100 \\
\hline Turkey & 6097 & 6460 & 12264 & 24821 \\
\hline$\%$ & 24.6 & 26.0 & 49.4 & 100 \\
\hline The share of Istanbul in Turkey\% & 0.4 & 25.5 & 23.0 & 18 \\
\hline
\end{tabular}

Source: TKB, TÜIKK 2012

Although most of the industrial facilities within Istanbul province are gathered in organized industrial zones as well as small industrial areas, as a result of unplanned structuring, a part of the industry remains within the settlement areas. $76 \%$ of the industrial facilities in Istanbul are on the European side, while $24 \%$ are on the Asian side. On the European side İkitelli, Beylikdüzü, Hadımköy and Kıraç are the intensely industrialized areas while Tuzla and Ümraniye are the heavily industrialized areas on the Anatolian side. According to the data from the Istanbul Chamber of Industry (ISO), approximately $6 \%$ of the industrial facilities in Istanbul province are located within Ümraniye District.

\section{FACTORS THAT HAVE AN IMPACT ON THE INDUSTRY IN ÜMRANIYE DiSTRICT}

One of the most significant features of modern industry is to have a location which can economically supply raw materials. However, nowadays, access to raw materials is facilitated by the development of transport systems, as well as industrial facilities and technological development becoming complex. Other factors, such as the market and labor, are also important (Tümertekin, Özgüç, 2005: 433). The reason why industrial facilities have been established in Ümraniye District is not the proximity to raw materials and energy sources but the opportunities supplied by proximity to the market, sectoral expertise and transport. The easy accessibility of energy, which is necessary particularly for industry, through the interconnected system, is gradually diminishing the importance of the location factor as it has in terms of the employment area.

Despite intensive mechanization, accessibility to qualified labor and its cost remains as an important factor in industry (Tümertekin, Özgüç, 2005: 434). In general, the branches of industry guarantee a high number of employed people. That is because the workforce that uses the modern tools and equipment also hold the major share in terms of productivity. Furthermore, the affiliation of industry with a large workforce has mainly established linear relationships between industrial activities and population density. 
Tab. 2. In Ümraniye District population distribution and density of the neighbourhood

\begin{tabular}{|l|r|l|r|l|r|r|r|}
\hline $\begin{array}{c}\text { Name of } \\
\text { Neighbourhood }\end{array}$ & $\begin{array}{c}\text { Area } \\
\text { (Ha.) }\end{array}$ & Population & $\begin{array}{c}\text { Density } \\
\text { (Person/ } \\
\text { Ha.) }\end{array}$ & $\begin{array}{c}\text { Name of } \\
\text { Neighbourhood }\end{array}$ & $\begin{array}{c}\text { Area } \\
\text { (Ha.) }\end{array}$ & Population & $\begin{array}{c}\text { Density } \\
\text { (Person/ } \\
\text { Ha. })\end{array}$ \\
\hline Adem Yavuz & 77 & 16441 & 214 & İnkllap & 204 & 26879 & 132 \\
\hline Altınşehir & 85 & 27124 & 319 & İstiklal & 101 & 45332 & 449 \\
\hline Armağan Evler & 111 & 31613 & 285 & K.Karabekir & 81 & 17846 & 220 \\
\hline Aşağı Dudullu & 95 & 11641 & 123 & Madenler & 92 & 11430 & 124 \\
\hline Atakent & 96 & 21574 & 225 & Mehmet Akif & 74 & 20027 & 271 \\
\hline Atatürk & 76 & 25143 & 331 & Namık Kemal & 81 & 28194 & 348 \\
\hline Cemil Meriç & 160 & 22623 & 141 & Necip Fazıl & 166 & 24104 & 145 \\
\hline Çakmak & 86 & 32306 & 376 & Parseller & 98 & 13557 & 138 \\
\hline Çamlık & 117 & 19491 & 167 & Saray & 179 & 1538 & 9 \\
\hline Dumlupınar & 104 & 13904 & 134 & Site & 218 & 23333 & 107 \\
\hline Elmalıkent & 122 & 22286 & 183 & Şerifali & 123 & 5952 & 48 \\
\hline Esenevler & 70 & 25227 & 360 & Tantavi & 54 & 8756 & 162 \\
\hline Esenkent & 385 & 15259 & 40 & Tatlisu & 102 & 16481 & 162 \\
\hline Esenşehir & 170 & 16983 & 100 & Tepeüstü & 43 & 13463 & 313 \\
\hline Fatih Sultan & 417 & 3626 & 9 & Topağac1 & 131 & 16427 & 125 \\
\hline Hekimbaş1 & 165 & 8737 & 53 & Yaman Evler & 73 & 12258 & 168 \\
\hline Huzur & 59 & 10806 & 183 & Yukarı Dudullu & 179 & 18469 & 103 \\
\hline Ihlamurkuyu & 137 & 16407 & 120 & Toplam & 4531 & 645237 & 255 \\
\hline
\end{tabular}

Source: Ümraniye Municipality; TÜIK (2012)

Ümraniye District, ranks in third place, after Bağcılar and Küçükçekmece, in terms of population in Istanbul province, with 645237 people, whichconstitutes 19\% (13 854740 people) of the population of Turkey (75 627384 people). $71.5 \%$ of the population, that is $2 / 3$, consist of active population (TÜIK, 2012). In 2012, the population density of the district was 255 per hectare. The most densely populated neighborhoods are also the neighborhoods of İstiklal, Çakmak, Esenevler, Namık Kemal and Atatürk, where the housing areas are mainly concentrated, while the neighborhoods of Esenkent, Esenşehir ve Yukarı Dudullu are the areas where industrialization and industrial facilities are concentrated and population density is smaller (Tab. 2).

Transportation which is an indispensable element in the development of industry in terms of raw material supply, has also become a positive factor for the work area in the field of transport.. Maritime lines (Tuzla and Hardarpaşa Ports) as well as highways (E-80 and D 100) and airways (Sabiha Gökçen Airport) are important advantages for Ümraniye in terms of transport. Ümraniye has especially used its position on an international transit high route to its advantage, to advance its industrialization and development. The district is located on the Europe-Asia route and between the Edirne-Ankara section, as well as in a central position to the express connections of the E-80 and D-100 state highway which is the most important highway in Turkey (Fig. 1). 
Because of its location Ümraniye is right in the center of a major market. The most important of these markets is Istanbul province and its hinterland. The industrial facilities in the district appeal to national and international markets as well as the local market. Most of the industrial facilities in the study area belong to the private sector and have been established with the owner's equity. In addition to local operations, with the impact of globalization foreign capital investments are also observed in the district. Especially the companies active in base metals, goods manufactured from metal, machinery-equipment and transport vehicles, as well as those in the electric-electronic and the informatics industry, are significant to the national and international markets.

\section{THE DEVELOPMENT AND SECTORAL DIVISION OF INDUSTRY IN ÜMRANIYE DisTRICT}

Industry has selected Istanbul as a foundation to agglomerate external economies and benefit from them with the largest and the most important market in Turkey, where easy access to economic raw materials and labor is ensured with top level technical infrastructure, accessibility and social accessories. In the first half of the 1980's, when the economy of Turkey was undergoing a transformation, $53 \%$ of the total number of medium and large scale industrial facilities and approximately $40 \%$ of the workforce employed in medium and large scale industrial facilities were based in Istanbul.

Istanbul, which has always been a locomotive in terms of migration from rural areas to urban areas, which was particularly popular after the 1950's, has had more than its share. The population masses arriving from the rural areas started to settle in the outskirts of the city. Ümraniye, which is the study area, has also hosted the inflow of the population from rural areas. Especially the intense migration during the 1970's, combined with the development in the industry resulted in Ümraniye becoming a municipality in 1963 and a district in 1987. After this period the population growth in the district accelerated and developed rapidly with industrialization.

There are 745 active manufacturing industry facilities in the study area. While $62.28 \%$ (464) of them are small industrial facilities employing less than 25 people, $37.72 \%$ (281) are medium and large scale industrial facilities employing 25 and more workers. 34 (4.56\%) of these facilities were established before the year 1980 while 711 (95.44\%) were established after the year 1980. 35128 workers were employed in the industrial facilities in Ümraniye District as of 2013. 28723 (81.8\%) of these workers are employed by facilities which employ 25 and more workers while $6405(18.2 \%)$ are employed by facilities which employ 25 and less workers. At the same time, $92.17 \%$ of the medium and large scale industrial facilities in the study area and $97.41 \%$ of the small scale operations opened for business after the year 1980 (Tab. 3). Although the economic crisis in Turkey, which took place in 2001, as well as the economic crises which occured on a global scale, had a negative impact on both large and small scale operations. These crises caused a decrease mostly in small scale operations and even caused a part of them to shut down. 
Tab. 3. Distribution of industrial facilities in Ümraniye District

\begin{tabular}{|c|c|c|c|c|c|c|}
\hline \multirow[b]{2}{*}{$\begin{array}{c}\text { Establishment } \\
\text { Period }\end{array}$} & \multicolumn{2}{|c|}{25 Employees and over } & \multicolumn{2}{|c|}{25 Employees and under } & \multicolumn{2}{|c|}{ Total } \\
\hline & 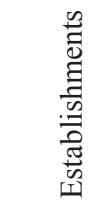 & 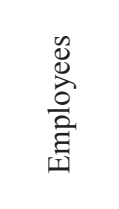 & 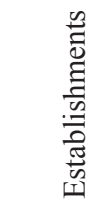 & 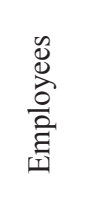 & 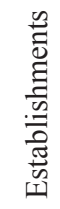 & 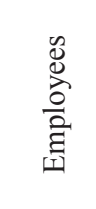 \\
\hline Before -1960 & 1 & 1483 & 0 & 0 & 1 & 1483 \\
\hline 1961-1980 & 21 & 6569 & 12 & 151 & 33 & 6720 \\
\hline $1981-2000$ & 77 & 12231 & 79 & 994 & 156 & 13225 \\
\hline $2001-2013$ & 182 & 8440 & 373 & 5260 & 555 & 13700 \\
\hline Total & 281 & 28723 & 464 & 6405 & 745 & 35128 \\
\hline
\end{tabular}

Source: Istanbul Chamber of Industry (İSO 2013).

$0.1 \%$ ( 1 facility) employing 25 and more workers in the district opened for operation before the year 1960, 4.4\% (33 facilities) started operating between the years 1961-1980, $20.9 \%$ (156 facilities) started operating between the years 1981-2000 and 74.5\% (555 facilities) opened after the year 2000. These numbers show the rapid increase of industrialization in Ümraniye from the past to the present. The number of facilities, which was 156 before the year 1980, increased rapidly after that year and reached 555 facilities by the year 2000 and increased to 745 during the period between the year 2000 and 2013. The fact that Ümraniye was given the status of a district in 1987 and that Ümraniye was declared Dudullu Organized Industrial Zone in 1995 played a significant part in the industrialization. Dudullu Organized Industrial Zone consists of IMES, DES and KADOSAN industrial sites and a factory area. Furthermore, there are 9 more industrial sites within the district boundaries, where small and large scale industrial facilities have conglomerated ${ }^{1}$ (Tab. 3).

Tab. 4. In Ümraniye District distribution of industrial facilities

\begin{tabular}{|l|c|c|c|c|c|c|c|c|c|c|}
\hline \multirow{2}{*}{ Sectors* } & \multicolumn{2}{|c|}{ Before 1960 } & $1961-1980$ & $1981-2000$ & \multicolumn{2}{|c|}{$2001-2013$} & \multicolumn{2}{c|}{ Total } \\
\cline { 2 - 12 } & A & B & A & B & A & B & A & B & A & B \\
\hline $\begin{array}{l}\text { The food-beverage and } \\
\text { tobacco industry }\end{array}$ & 1 & 1483 & 1 & 8 & 10 & 1616 & 27 & 1109 & 39 & 4216 \\
\hline $\begin{array}{l}\text { Base metals, goods } \\
\text { manufactured from } \\
\text { metal, machinery- } \\
\text { equipment and transport } \\
\text { vehicles }\end{array}$ & 0 & 0 & 15 & 719 & 71 & 6440 & 238 & 4894 & 324 & 12053 \\
\hline $\begin{array}{l}\text { Weaving, ready to } \\
\text { wear and leather } \\
\text { manufacturing }\end{array}$ & 0 & 0 & 2 & 93 & 19 & 2455 & 69 & 2161 & 90 & 4709 \\
\hline $\begin{array}{l}\text { Wood and wood } \\
\text { manufacture, products } \\
\text { including furnitures }\end{array}$ & 0 & 0 & 2 & 44 & 5 & 136 & 57 & 1372 & 64 & 1552 \\
\hline
\end{tabular}

${ }^{1}$ Modoko, Keyap, Fatih Sultan Mehmet, Güven, Deniz, Gümrükçüler, Ak, Birlik ve Özantaş Industry Sites. 


\begin{tabular}{|l|r|r|r|r|r|r|r|r|r|r|}
\hline $\begin{array}{l}\text { Paper-paper products } \\
\text { and printing }\end{array}$ & 0 & 0 & 0 & 0 & 1 & 218 & 13 & 260 & 14 & 478 \\
\hline $\begin{array}{l}\text { Chemicals, petroleum, } \\
\text { rubber and plastic }\end{array}$ & 0 & 0 & 4 & 1067 & 12 & 396 & 49 & 1074 & 65 & 2537 \\
\hline Based on rock and soil & 0 & 0 & 2 & 357 & 9 & 411 & 22 & 450 & 33 & 1218 \\
\hline $\begin{array}{l}\text { Electric-electronic and } \\
\text { informatics }\end{array}$ & 0 & 0 & 7 & 4432 & 29 & 1553 & 80 & 2380 & 116 & 8365 \\
\hline Total & 1 & 1483 & 33 & 6720 & 156 & 13225 & 555 & 13700 & 745 & 35128 \\
\hline
\end{tabular}

Source: İSO 2013, *Total, A - Establishments, B - Employees

Tab. 5. In Ümraniye District distribution of industrial facilities

\begin{tabular}{|c|c|c|c|c|c|c|c|c|c|c|}
\hline \multirow{2}{*}{ Sectors* } & \multicolumn{2}{|c|}{ Before 1960} & \multicolumn{2}{|c|}{$1961-1980$} & \multicolumn{2}{|c|}{$1981-2000$} & \multicolumn{2}{|c|}{$2001-2013$} & \multicolumn{2}{|c|}{ Total } \\
\hline & $\mathrm{A}$ & $\mathrm{B}$ & $\mathrm{A}$ & $\mathrm{B}$ & $\mathrm{A}$ & \begin{tabular}{|l|}
$\mathrm{B}$ \\
\end{tabular} & $\mathrm{A}$ & $\mathrm{B}$ & A & $\mathrm{B}$ \\
\hline $\begin{array}{l}\text { The food-beverage and } \\
\text { tobacco industry }\end{array}$ & 1 & 1483 & 0 & 0 & 9 & 1594 & 13 & 881 & 23 & 3958 \\
\hline $\begin{array}{l}\text { Base metals, goods } \\
\text { manufactured from metal, } \\
\text { machinery-equipment and } \\
\text { transport vehicles }\end{array}$ & 0 & 0 & 10 & 644 & 27 & 5905 & 58 & 2302 & 95 & 8851 \\
\hline $\begin{array}{l}\text { Weaving, ready to wear } \\
\text { and leather manufacturing }\end{array}$ & 0 & 0 & 1 & 70 & 13 & 2377 & 35 & 1690 & 49 & 4137 \\
\hline $\begin{array}{l}\text { Wood and wood } \\
\text { manufacture, products } \\
\text { including furnitures }\end{array}$ & 0 & 0 & 1 & 30 & 3 & 112 & 20 & 839 & 24 & 981 \\
\hline $\begin{array}{l}\text { Paper - paper products } \\
\text { and printing }\end{array}$ & 0 & 0 & 0 & 0 & 1 & 218 & 2 & 104 & 3 & 322 \\
\hline $\begin{array}{l}\text { Chemicals, petroleum, } \\
\text { rubber and plastic }\end{array}$ & 0 & 0 & 3 & 1054 & 5 & 310 & 14 & 605 & 22 & 1969 \\
\hline Based on rock and soil & 0 & 0 & 1 & 349 & 3 & 342 & 6 & 220 & 10 & 911 \\
\hline $\begin{array}{l}\text { Electric-electronic and } \\
\text { informatics }\end{array}$ & 0 & 0 & 5 & 4422 & 16 & 1373 & 34 & 1799 & 55 & 7594 \\
\hline Total & 1 & 1483 & 21 & 6569 & 77 & 12231 & 182 & 8440 & 281 & 28723 \\
\hline
\end{tabular}

Source: İSO 2013. *25 Employees and over, A - Establishments, B - Employees

There are 10 facilities in Ümraniye District with both national and international manufacturing, employing more than 500 workers, and 41 facilities which employ 100 and more workers, 9 of these facilities being among the leading 500 large scale industrial facilities in Turkey. These companies are Oyak Renault Automobile Factories, Unilever, Coca Cola Beverage, Delphi Automotive, Bayer Chemicals ABB Electric, İzocam Glass Industry, Sunjüt Fabrics, and Umur Basım industrial. Some of the other large companies worth mentioning are BHS Household Equipment, Görkem Ready to Wear, Frito Lay Foods, Bayer Türk Chemicals, Gamak Machinery, Huzur Ready to Wear, Nobel Drugs, Huzur Ready to Wear, Casper Computer, Anel, and Netaş Telecommunication industries. There are $11 \mathrm{com}-$ panies operating in the weaving, ready to wear and leather manufacturing sector, 10 companies within the electric-electronic and informatics industry sector, 10 companies in the base 
metals, goods manufactured from metal, machinery-equipment and transport vehicles sector, 7 companies in the food, beverages and tobacco sector, 6 companies deal with chemicals, petroleum, rubber and plastic industries sector, 4 companies within with industrial sectors based on rock and soil, 2 in paper - paper products and printing while 1 is within the operating activities, all of which employ over 100 people in the district.

Tab. 6. In Ümraniye District distribution of industrial facilities

\begin{tabular}{|l|c|c|r|r|r|r|r|r|r|r|}
\hline \multirow{2}{*}{ Sectors* } & \multicolumn{2}{|c|}{ Before 1960 } & \multicolumn{1}{c|}{$1961-1980$} & \multicolumn{1}{c|}{$1981-2000$} & \multicolumn{2}{c|}{$2001-2013$} & \multicolumn{2}{c|}{ Total } \\
\cline { 2 - 12 } & A & B & \multicolumn{1}{c|}{ A } & B & A & B & A & B & A & B \\
\hline $\begin{array}{l}\text { The food-beverage and } \\
\text { tobacco industry }\end{array}$ & 0 & 0 & 1 & 8 & 1 & 22 & 14 & 228 & 16 & 258 \\
\hline $\begin{array}{l}\text { Base metals, goods } \\
\text { manufactured from metal, } \\
\text { machinery-equipment and } \\
\text { transport vehicles }\end{array}$ & 0 & 0 & 5 & 75 & 44 & 535 & 180 & 2592 & 229 & 3202 \\
\hline $\begin{array}{l}\text { Weaving, ready to wear } \\
\text { and leather manufacturing }\end{array}$ & 0 & 0 & 1 & 23 & 6 & 78 & 34 & 471 & 41 & 572 \\
\hline $\begin{array}{l}\text { Wood and wood } \\
\text { manufacture, products } \\
\text { including furnitures }\end{array}$ & 0 & 0 & 1 & 14 & 2 & 24 & 37 & 533 & 40 & 571 \\
\hline $\begin{array}{l}\text { Paper - paper products } \\
\text { and printing }\end{array}$ & 0 & 0 & 0 & 0 & 0 & 0 & 11 & 156 & 11 & 156 \\
\hline $\begin{array}{l}\text { Chemicals, petroleum, } \\
\text { rubber and plastic }\end{array}$ & 0 & 0 & 1 & 13 & 7 & 86 & 35 & 469 & 43 & 568 \\
\hline Based on rock and soil & 0 & 0 & 1 & 8 & 6 & 69 & 16 & 230 & 23 & 307 \\
\hline $\begin{array}{l}\text { Electric-electronic and } \\
\text { informatics }\end{array}$ & 0 & 0 & 2 & 10 & 13 & 180 & 46 & 581 & 61 & 771 \\
\hline Total & 0 & 0 & 12 & 151 & 79 & 994 & 373 & 5260 & 464 & 6405 \\
\hline
\end{tabular}

Source: İSO 2013. *25 Employees and under, A - Establishments, B - Employees

\section{AND THE PRECEDING PERIOD}

According to the data from the Istanbul Chamber of Industry, the number of facilities opened for operation before 1980 was 34.22 of the facilities were organizations which employed 25 and more workers, while 12 of them employed 25 and less employees. A review of the distribution of these industrial organizations in terms of sectors shows, that 15 establishments (10 of them large scale industry) are leaders in the industry of base metals, goods manufactured from metal, machinery-equipment and transport vehicles. This is followed by 7 businesses ( 5 of them large scale industry) in the electric-electronic and informatics industry, 4 facilities ( 1 of them large scale industry) within the chemicals, petroleum, coal, rubber and plastic products industry as well as 2 for each of the other industrial sectors. A total of 8203 workers are employed in the 34 facilities which opened for business before the year 1980 . During this period, 98\% (8052) of the employees were working in large establishments, while the remaining 151 were employed by small scale businesses. With 4,432 employees 
(99.8\% in large industries), the electric-electronic and informatics industry was the leading sector in terms of employment. This sector was followed by the food-beverage and tobacco industry with 1491 (99.5\% in large scale industry) employees, the chemicals, petroleum, coal, rubber and plastic products sector with 1067 (98.8\% in large scale industry) people, the base metal, goods manufactured from metal, machinery-equipment and transport vehicles industry with $719(89.6 \%$ in large scale industry) employees and other industrial sectors with 494 employed (Tab. 4-6).

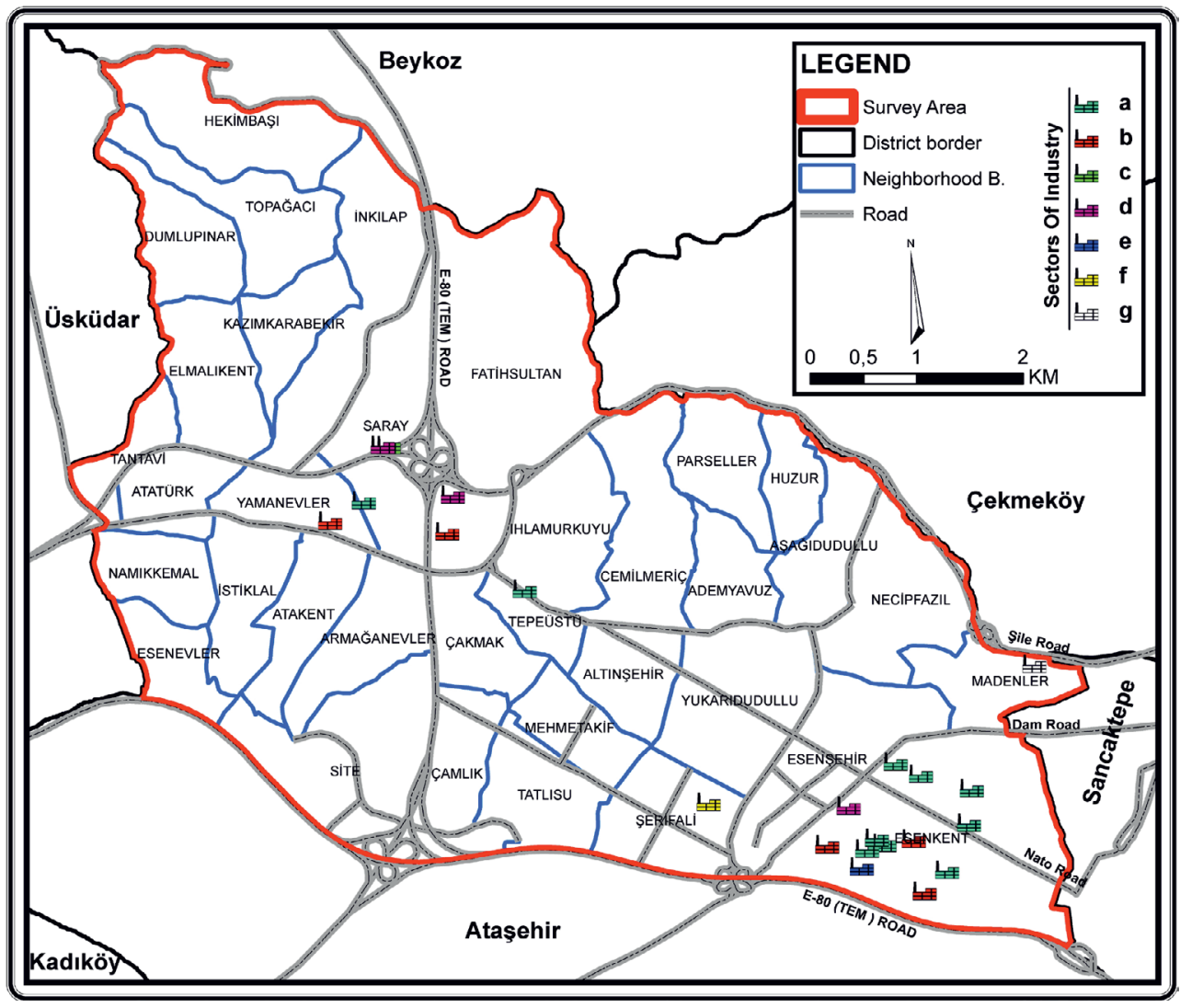

Fig. 2. Distribution of the industrial establishments in Ümraniye District (before 1980, 25 employees and over)

Explanation: a - Base metals, goods manufactured from metal, machinery-equipment and transport vehicles, $\mathrm{b}$ - Electric-electronic and informatics, $\mathrm{c}-$ The food-beverage and tobacco industry, $\mathrm{d}$ - Chemicals, petroleum, rubber and plastic, $\mathrm{e}-$ Based on rock and soil, $\mathrm{f}$ - Weaving, ready to wear and leather manufacturing, $\mathrm{g}-$ Wood and wood manufacture, products including furnitures.

The first large scale industrial facility to be established in Ümraniye District is Unilever Food Industries, which opened in 1952 and employs 1483 people today. This company is the largest worldwide producer of the fast moving consumer goods on an international scale and produces food, beverages, household and personal care products. In the same period Izocam, 
which employs 349 staff, and ABB electricity, which employs 546 individuals, were established in 1966, Bayer Türk Kimya which employs 631 people and Netaş Telecommunication employing 400 people were established in 1967, Gamak Machinery with 628 people was established in 1969 and BSH Household Tools employing 2808 staff was established in 1975. These companies were leaders in the industrialization of the work area and the first large scale industrial organizations to open for business. Most of these industrial facilities, established before 1980, concentrated in the western part of the district along the E-80 highway in the neighborhoods of Saray, Fatihsultan, Çakmak, İnkılap and Ihlamurkuyu. After the Dudullu Region was selected to become the Organized Small Arts and Industry Area in 1977, within the framework of the Planned Development Strategies of Turkey industrial organizations started to select locations around neighborhoods which are today known as Esenkent, Esenşehir, Madenler and Şerifali (Fig. 2).

\section{THE PERIOD OF 1980 AND ONWARDS}

$21 \%$ of the industrial businesses established in Ümraniye District were opened during the 1981-2000 period. During this period a total of 156 businesses were established 77 of which were medium and large scale facilities, and 79 were small scale facilities. The leading sector among the industrial facilities opening for business was the base metal, metal goods, machinery-equipment and transportation vehicles industry with 71 facilities (27 of which were large scale). This sector was followed by 29 (16 of which were large scale) electric-electronic and informatics industry facilities, 19 weaving, ready to wear and leather processing industries (13 of which were large scale), 12 chemical, petroleum, rubber and plastic industries ( 5 of which were large scale) and 25 facilities within other industrial sectors. A total of 13225 people are employed in 156 enterprises which were established during the 1981-2000 period. More than 92\% of the employees during that period (12 231 people) worked in large scale enterprises while the remaining 994 people were employed by small scale facilities. The base metal, metal goods, machinery-equipment and transportation vehicles industry was the leading sector in terms of employment with 6440 workers $(91.7 \%$ in large scale operations). This sector was followed by the weaving, ready to wear and leather processing industries with 2455 employees (96.8\% in large scale operations), the food, beverages and tobacco products industries with 1616 employees $(98.6 \%$ in large scale operations), electric-electronic and informatics industry with 1553 employees (88.4\% in large scale operations) and 1161 employees working in other industrial sectors (Tab. 4-6).

Out of the enterprises which opened for business during 1981-2000 in the study area, the enterprise which was the leader in terms of staff was the Oyak-Renault Automotive Industry, which was established in 1983 and currently employs 3363 people. With the ability of this company to manufacture regionally and on an international scale, Turkey is also a major automotive manufacturer in a regional sense. Frito Lay which employs 689 people was also established during this period in 1966, Görkem Ready to Wear which employs 800 people 
was established in 1987, Delphi Automotive employs 1104 personnel and was established in 1989, Coca-Cola which was established in 1990 and Huzur Ready to Wear which was established in 1991 and employs 500 people are among major enterprises which serve the food products industry, ready to wear industry, auto spare parts industry and beverage industry respectively. These enterprises also manufacture products for the international market. During the 1981-2000 period, the area in the eastern part of the district, where the neighborhoods of Esenkent, Esenşehir, Yukarıdudullu and Şerifali are located, became a location of a large number of industrial facilities. The opening of IMES in 1986, DES and KADOSAN industrial areas in 1996 had an effective role in the establishment of Dudullu Organized Industrial zone in 1995, which also included these industrial areas (Fig. 3).

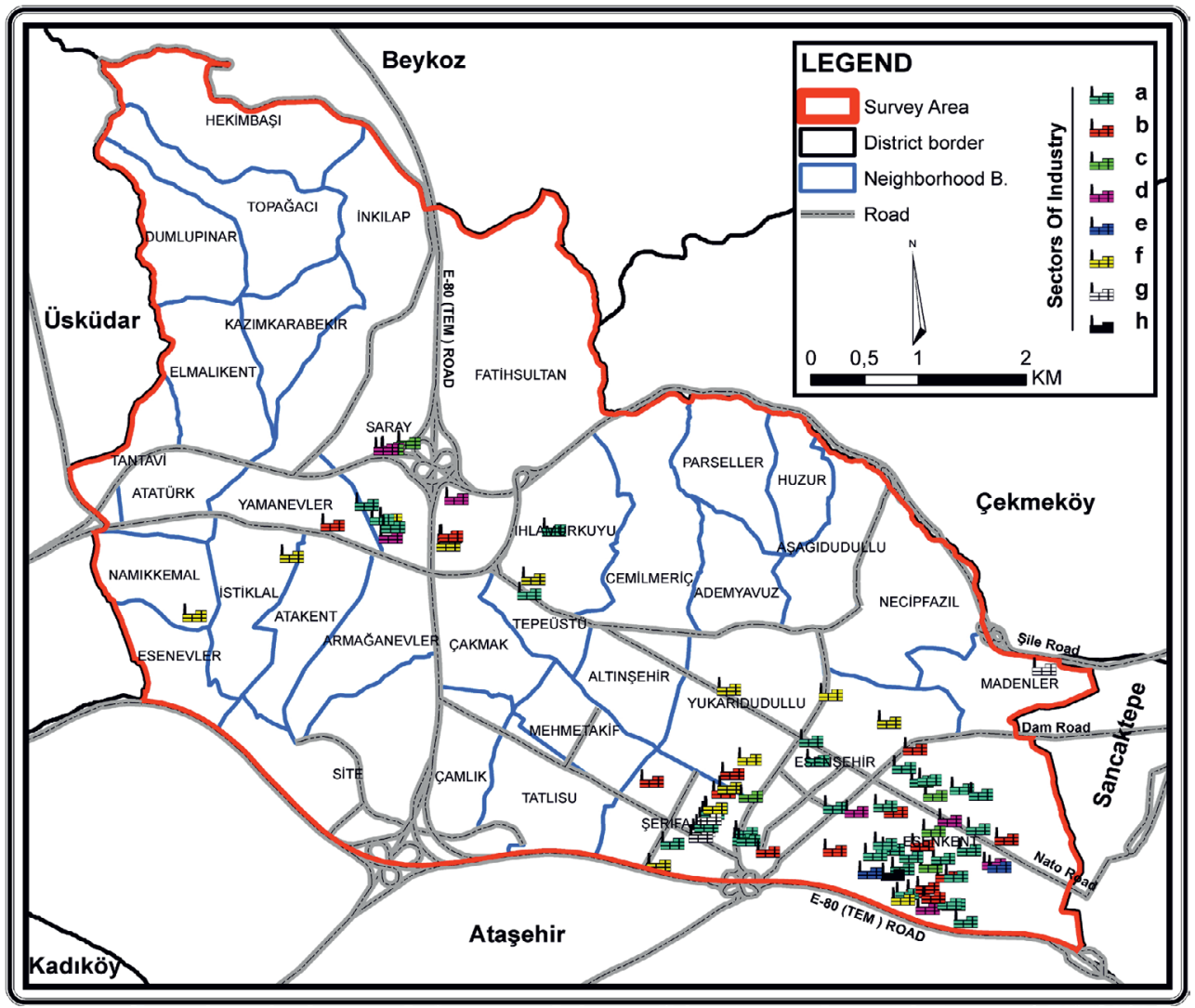

Fig. 3. Distribution of the industrial establishments in Ümraniye District (1981-2000, 25 employees and over)

Explanation: a - Base metals, goods manufactured from metal, machinery-equipment and transport vehicles, $\mathrm{b}$ - Electric-electronic and informatics, $\mathrm{c}-$ The food-beverage and tobacco industry, $\mathrm{d}$ - Chemicals, petroleum, rubber and plastic, $\mathrm{e}-$ Based on rock and soil, $\mathrm{f}$ - Weaving, ready to wear and leather manufacturing, $\mathrm{g}-$ Wood and wood manufacture, products including furnitures, $\mathrm{h}$ - Paper - paper products and printing. 
The highest number of industrial businesses to start operating in Ümraniye was during the years 2001-2013, with 555 facilities. $74.5 \%$ of the industrial facilities in the district started operating during this period. 182 of the industrial facilities which started operating are medium and large scale operations while 373 are small scale operations. The leading sector among the industrial organizations which started operating during the 2001-2013 period was the base metal, metal goods, machinery-equipment and transport vehicles industry with 238 organizations (58 are large scale). This sector was followed by the electric-electronic and informatics industry with 80 facilities (34 are large scale), the weaving, ready to wear and leather processing industry with 69 facilities (35 are large scale), forest products and furniture manufacturing industry with 57 facilities (20 are large scale), the chemical, petroleum, rubber and plastic industry with 49 facilities (20 are large scale) and other industrial sectors with 62 facilities.

A total of 13700 workers were employed in 555 facilities established during the 2001-2013 period. More than 61.6\% (8,440 people) employed during this period worked in large scale establishments while the remaining 5260 worked in small scale establishments. With 4894 laborers (47\% in large scale industries), the base metal, metal goods, machinery-equipment and transport vehicles industry was the leading sector in terms of employment. This sector was followed by the electric-electronic and informatics industry with 2380 employees (75.6\% in large scale industries), the weaving, ready to wear and leather processing industry with 2161 employees (78.2\% in large scale industries), the forest products and furniture manufacturing industry with 1372 employees $(61.2 \%$ in large scale industries) and other industrial sectors with 2893 employees (Tab. 4-6). Out of the facilities which opened in Ümraniye District in and after 2001 enterprises which have the most employees - Divan Unlu Mamuller which was established in 2006 and employs 328 people, Aneles Electronic which was established in 2001 and employs 230 people and Anel Telecommunications which was established in 2003 and employs 214 people - are major organizations which manufacture convenience foods, electronic cards and electronic communication systems respectively.

$62 \%$ of the 183 medium and large scale industrial facilities which started operating during the 2001-2013 period are located in the neighborhoods of Esenkent, Esenşehir, Yukarıdudullu and Şerifali, which are located in the Dudullu Organized Industrial zone, while 38\% are situated in the neighborhoods of Saray, İnk1lap, Ihlamurkuyu, Armağanevler, Altınşehir and along the major boulevards and avenues of the district (Fig. 4). The industry has expanded to the areas other than the access routes in the district, small scale industrial sites, the organized industrial zone and dense urban areas. It is observed that industry is mainly concentrated on the E-80 (TEM) international highway, Istanbul-Şile, Nato, Baraj, Yukarıdudullu-Bostancı highways, Bayraktar Boulevard, Alemdağ, Küçüksu, Barbaros, Tavukçuyolu avenues, and their vicinies. As indicated on the urban functions map of Ümraniye District, these avenues are also the places where official areas, administrative facilities, central commerce and business areas, wholesale markets and other commercial areas are concentrated (Fig. 1-4). 


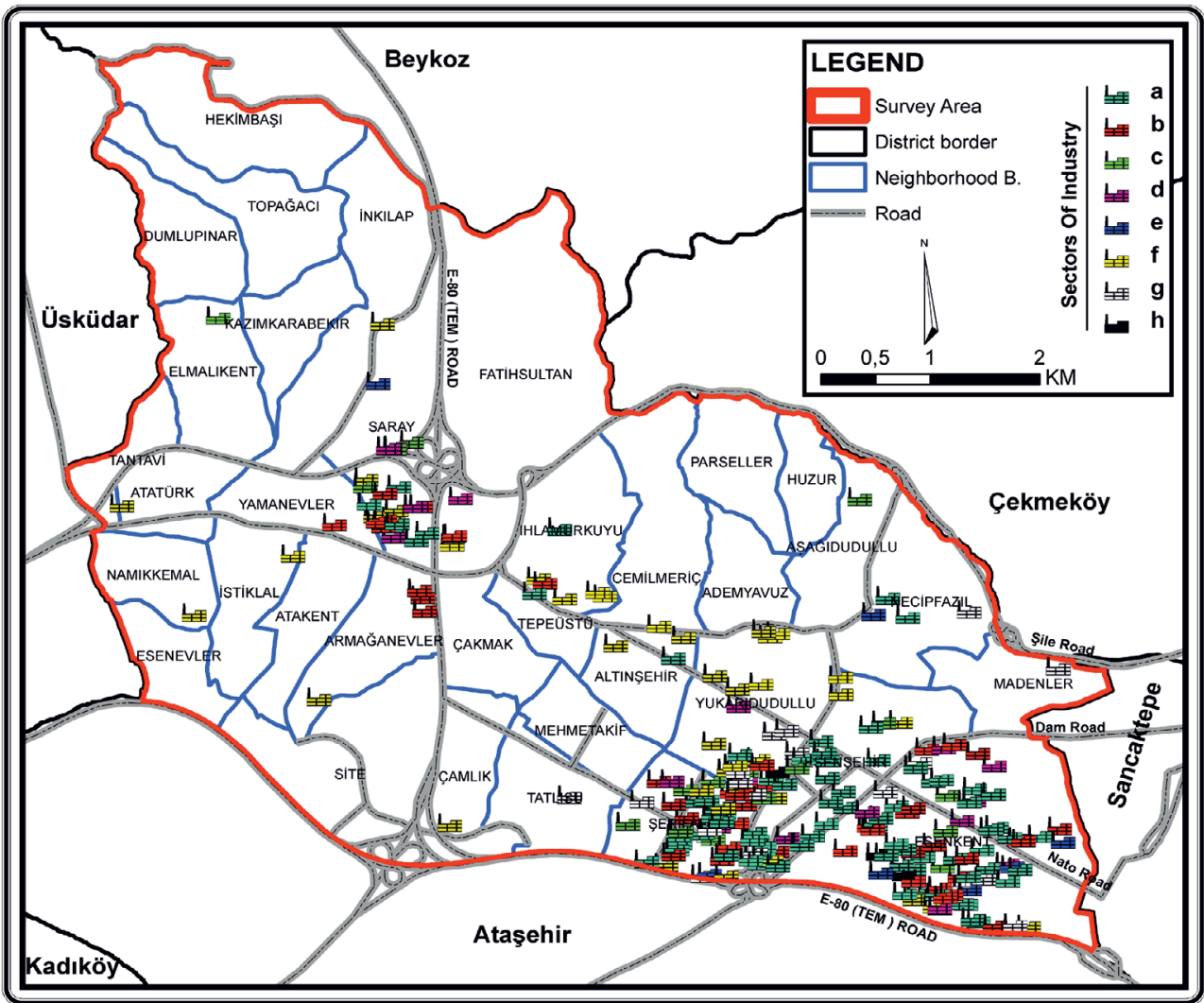

Fig. 4. Distribution of the industrial establishments in Ümraniye District (2001-2013, 25 employees and over)

Explanation: a - Base metals, goods manufactured from metal, machinery-equipment and transport vehicles, $\mathrm{b}$ - Electric-electronic and informatics, $\mathrm{c}-$ The food-beverage and tobacco industry, $\mathrm{d}$ - Chemicals, petroleum, rubber and plastic, e - Based on rock and soil, f: Weaving, ready to wear and leather manufacturing, g: Wood and wood manufacture, products including furnitures, h: Paper - paper products and printing

\section{Conclusion}

The study area is located within the boundaries of Istanbul Province and it is a development area which has been subjected to the most rapid urbanization, industrialization combined with an intense concentration of population for the past 30 years. The district is located within Marmara Region, which is the most developed region in Turkey, on the 0-2 and 0-4 routes of the E-80 (TEM) motorway which is the most important highway in Turkey. Almost all of the industrial facilities in Ümraniye are spatially dispersed in the areas in the vicinity of these access routes, and the highway access routes in particular have a major impact on the establishment area of the industry. In addition, the main reason for the establishment of 
industrial facilities in Ümraniye is the presence of a large organized industrial zone in the district. The fact that the district is close to the market, the specialization of the industry in terms of sectors in the district, and the district being one of the developed areas of Istanbul are other factors which have an influence on the presence of industry in the district.

The industrialization, which started during the 1960's in Ümraniye, continued to develop exponentially in later periods. The industry in the district displayed major development, especially with the facilities which were opened after the year 2001. Many companies in the study area are involved in both national and international activity areas; 745 industrial facilities in the district employ 35128 people. While $62.28 \%$ of these facilities are small scale industrial facilities employing less than 25 laborers, $37.72 \%$ are medium and large scale industrial facilities which employ 25 and more laborers. 28723 people are employed by medium and large scale industrial facilities (281 enterprises) while 6405 people are employed by small scale industrial facilities (464 enterprises).

Before the year 1980, industrial facilities were concentrated in the central neighborhoods and Esenkent Neighborhood of the city in the study area; they started to settle within and around the industrial areas which opened after 1980. With the announcement of Dudullu Organized Industrial Zone, which is one of the 8 organized industrial zones in Istanbul, in 1995, industrial facilities started to concentrate in the eastern and southeastern parts of the district. During the first period, industrial facilities, which were concentrated in two separate areas, and particularly after the year 2000, started to develop and converge along the Nato Road route. Although most of the industrial facilities established in the study area before the year 2000 consisted of medium and large scale industrial facilities, due to the economic crises of 2001 and 2008 most of the industrial facilities opened after the year 2000 were small scale industrial facilities. The small scale industrial facilities which were affected the most by these two crises started to reopen for business during subsequent years. Although there is a significant recession in terms of the numbers of industrial facilities opened during times of crisis, a significant increase in the number of opened facilities has been observed during other years.

Because they were established in the past, a part of the industrial facilities in the study area have remained in the center of the areas which have developed as residential areas. These facilities must be relocated to more appropriate areas in the district. Furthermore, if the irregular settlement of industrial facilities is added to the unplanned housing, which is frequently observed in the district, it will be impossible to avoid irregular and haphazard settlements. For this reason some industrial facilities in the district continue operating in old and rundown buildings. These facilities must be relocated to organized industrial zones and industrial areas with modern and planned buildings. 


\section{References}

Buldam, A. (1981). Türkiye'de Küçük Sanayi Siteleri (Small industrial estates in Turkey - in Turkish). Ankara: Sosyal Planlama Başkanlığı, Planlama Dairesi.

Doğan, M. (2013). Geçmişten Günümüze İstanbul'da Sanayileşme Süreci ve Son 10 Yıllık Gelişimi, Marmara Coğr. Derg., S.27, 511-550, İstanbul.

Göney, S.E. (1995). Sehir Coğrafyası (Urban Geography), İstanbul: İstanbul Üniv. Edebiyat Fak. Basımevi.

İstanbul Valiliği Çevre ve Orman İl Müdürlüğ̈̈ 2006 - 2007 (Istanbul environmental status report - in Turkish), Istanbul: İst. Çevre ve Orman Müdürlügü Yay.

Karakuyu, M. (2008). Türkiye'de Sanayi Faaliyetlerinin Gelişmesi, Yapısı ve Dağıllı̧ı (The industrialization process of Hadımköy; factors of development, structures and problems - in Turkish). Marmara Geographical Review, 18, 21-49.

Mutluer, M. (1995). Gelişimi, Yapısı ve Sorunlarıyla Denizli Sanayi (Development, structure and problems of Denizli industrial sector - in Turkish), Izmir: Ege Üniv. Basımevi.

Özerkmen, N. (1994). Türkiye'de Küçük Sanayinin Yapısı ve Bugünkü Durumu (Structure and current status of small industry in Turkey - in Turkish). Dil-Tarih Coğrafya Fakültesi Felsefe Bölümü Derg., 15, 275-292.

Özgüç, N. (1986-1987). Türkiye'de Sanayi Faaliyetlerinin Gelişmesi, Yapısı ve Dağılışı (The development of industrial activities in Turkey, structure and distribution - in Turkish). İstanbul Üniv. Ede. Fak. Coğrafya Derg., 2, 35-70.

Sanayi İstatistikleri (2013). (Industrial Statistics - in Turkish), Istanbul: İstanbul Sanayi.

Odas1 (ISO).

Serin, N. (1963). Türkiye'nin sanayileşmesi (The industrialization of Turkey - in Turkish). Ankara Üniv. Siyasal Bilgiler Fak.Yay 167-149, Ankara: Ankara Üniv, pp.115-116.

Sevgi, C. (1994), Sanayileşme Sürecinde Türkiye ve Sanayi Kuruluşlarının Alansal Dağılımı (The process of industrialization in Turkey and spatial distribution of industrial organizations - in Turkish). Istanbul: Beta basım.

Sevim, Ü. (2006). Tekstil ve Konfeksiyon Yan Sanayi (Textile and apparel industry - in Turkish). Ankara: IGEME.

Temurçin, K. (2004). Isparta İlinde Sanayinin Gelişimi ve Yapısı (Developoment and structure of industry in the Isparta Province - in Turkish). Ankara Üniv.Coğrafi Bilimler Derg., 2(2) 79-95.

Temurçin, K. (2013), The development and structure of industry in the district of Bağcılar, Istanbul. Bulletin of Geography. Socioeconomic Series, No. 95-111.

Türkiye İstatistik Kurumu (TÜIK), İstatistik verileri (Statistical data - in Turkish) (2012). Ankara.

Türkiye Kalkınma Bankası (TKB), İstatistik verileri (Statistical data - in Turkish) (2012). Ankara.

Tümertekin, E. (1967). İstanbul'da bir sanayi bölgesi: Bomonti (An industrial area in Istanbul: Bomonti - in Turkish). İstanbul Üniv. Yay., No. 1282.

Tümertekin, E. (1968-1969). The growth and changes in the central business district of Istanbul. The Review of the Geographical Institute of the University of Istanbul, 12, 27-37.

Tümertekin, E. (1970). İstanbul şehri ve Çevresinde Sanayi: Özellikler ve Dağıllş̧ (The industry of Istanbul City: characteristics and distribution - in Turkish). İstanbul Üniv. Coğrafya Enst. Derg., 17, 33-69.

Tümertekin, E. (1972), İstanbul Sanayinde Kuruluş Yeri (Istanbul industry organization - in Turkish). İstanbul Üniv. Yay., 1808.

Tümertekin, E. (1984), De L'etat actuel du developpement des activites industrielles en İstanbul (The current state of industrial activities in Istanbul - In French). Ege Coğrafya Derg., 2, 109-128.

Tümertekin, E., Özgüç, N. (2005). Ekonomik Coğrafya; Küreselleşme ve Kalkınma (Economic geography, globalization and development - in Turkish). Istanbul: Çantay Kitabevi. 


\section{Internet sources}

http://www.idosb.org.tr/kurumsal.php?P=47, DoA: 2013/11/05.

http://www.iso.org.tr/tr/web/StatikSayfalar/Kutuphane yayinlar detay.aspx\#86, DoA:2013/06/07.

http://www.kgm.gov.tr/SiteCollectionImages/KGMimages/Haritalar/b1.jpg, DoA:2013/07/10.

http://sehirrehberi.ibb.gov.tr/map.aspx, DoA:2013/06/10.

http://www.umraniye.bel.tr/bpi.asp?caid=60\&cid=9629, DoA:2013/01/22.

http://www.umraniye.gov.tr/default_B0.aspx?content=1031, DoA:2013/10/28.

http://www.tuik.gov.tr/VeriBilgi.do?alt_id=28, DoA:2013/06/05.

Dr. Kadir Temurçin, was born in Isparta/Turkey, in 1973. He graduated from Istanbul University, Faculty of Arts, Department of Geography in 1995. He completed his master's degree at the University of Istanbul "Isparta City" in 1998, and his Ph.D., "Isparta Province Economic Geography", at the University of Ankara in 2004. Temurçin, was titled an assistant professor in 2005, and an associate professor in 2011. He has been working as an academic at Süleyman Demirel University, Faculty of Arts and Sciences since 1998. Dr. Kadir Temurçin, has been working as an academic in the fields of economic geography, history, geography, land use, geography of crime. In the field of geography of crime, he published one book (Geography of Crime in Turkey-City Public Security Crimes), he is known in the field of geography journals, published two articles in Poland and Canada, and presented in two papers during international symposiums. His research studies feature the original analysis of the spatial distribution of crimes in Turkey. He published a book in historical geography studies, about the health and social geography in Lakes Region(S1hhî̀-İçtimâî Geography) and two articles about non-Muslims characteristics of the socio-economic structure and population in the 19th century during the Ottoman Empire as well as a study about the spatial aspect of change in provision of public services in rural areas and in particular an assessment of the impact of migration on the public services in rural areas. Dr. Temurçin related some of his other works to different fields in Turkey; industrial geography, tourism geography, energy resources, urban geography, population and migration. In total, more than 35 academic who has studied with Dr. Kadir Temurçin, focused academically in the field Crime of Geography and Historical Geography. Assoc. Prof. Dr. Kadir Temurçin is married and has one child.

Yolcu Aldırmaz, was born in Kars/Turkey, in 1989. He graduated from Süleyman Demirel University, Faculty of Arts and Sciences, Department of Geography in 2013. He has been working as an research assistant at Yüzüncü Y1l University, Faculty of Arts since 2014. Yolcu ALDIRMAZ has been working as an academic in the field of economic geography and land use.

\section{Adres/adress:}

Süleyman Demirel University

Art and Sciences Faculty

Department of Geography

32260 Isparta, Turkey

e-mail: kadirtemurcin@sdu.edu.tr

e-mail: kadirtemurcin@yahoo.com 